ANNALS OF

APPLIED BIOLOGY

\title{
Weed development in spring wheat after contrasting soil tillage and nitrogen management
}

\begin{tabular}{|r|l|}
\hline Journal: & Annals of Applied Biology \\
\hline Manuscript ID & AAB-2015-0364.R1 \\
\hline Manuscript Type: & Research paper \\
\hline Complete List of Authors: & $\begin{array}{l}\text { Rial-Lovera, Karen; Royal Agricultural University, School of Agriculture, } \\
\text { Food and Environment } \\
\text { Davies, William; Royal Agricultural University, School of Agriculture, Food } \\
\text { and Environment } \\
\text { Cannon, Nicola; Royal Agricultural University, School of Agriculture, Food } \\
\text { and Environment } \\
\text { Conway, John; Royal Agricultural Universi, School of Agriculture, Food and } \\
\text { Environment }\end{array}$ \\
\hline Key Words: & $\begin{array}{l}\text { weed management, reduced tillage, conventional tillage, N fertiliser, } \\
\text { broadleaf weed, grass weed }\end{array}$ \\
\hline
\end{tabular}


Running head: Weed development in spring wheat after soil tillage and nitrogen management

\section{Weed development in spring wheat after contrasting soil tillage and nitrogen management}

Karen Rial-Lovera, William Davies, Nicola Cannon \& John Conway

Royal Agricultural University, School of Agriculture, Food and Environment, Stroud Road Cirencester Gloucestershire GL7 6JS, UK

\section{Correspondence}

Dr. Karen Rial-Lovera, Royal Agricultural University, School of Agriculture, Food and Environment, Stroud road Cirencester Gloucestershire GL7 6JS, UK. Email:

karen.rial.lovera@gmail.com

\section{Keywords}

Weed management; reduced tillage; conventional tillage; $\mathrm{N}$ fertilizer; broadleaf weed; grass weed.

Received: 2 December 2015; revised verson accepted: 26 February 2016.

\section{Summary}

Soil tillage and nitrogen $(\mathrm{N})$ management effects on weed specie composition was evaluated in 2013 and 2014 on a clayey soil after 5-years of organic management at the Royal Agricultural University's Harnhill Manor Farm, UK. Three tillage systems - Conventional Tillage (CT), and High and Low Intensity Non-inversion Tillage (HINiT \& LINiT) - were compared at four $\mathrm{N}$ fertiliser rates of $0,70,140$ and $210 \mathrm{~kg} \mathrm{~N} \mathrm{ha}^{-1}$. Broad-spectrum herbicide was applied before soil operations across the site in both years. Previous organic management legacy of high weed biomass promoted greater weed prevalence in 2013 while 2-years of herbicide inclusion reduced weed biomass in 2014. Contrasting weather conditions across the seasons affected weed incidence. In the 2014 wet season, early weed dry weight (DM) was higher under HINiT than CT and LINiT, while no differences were observed in the 2013 dry year. At midseason, weed DM was higher under HINiT than CT and LINiT in both years, 
which was related to higher DM of the dominant weeds Stellaria media and Sinapsis arvensis. Grass weed DM was higher under non-inversion tillage than CT. N fertilisation increased midseason total weed DM and weed prevalence at harvest. Spring wheat yield was the highest under CT while LINiT produced 17\% higher yields than HINiT. Despite higher but still tolerable weed prevalence under both non-inversion tillage systems and with the application of $\mathrm{N}$, weeds alone was not the only yield-limiting factor. However, results show that $\mathrm{CT}$ is the most reliable option for weed control in changing weather, while $\mathrm{N}$ fertilisation rates needs to be considered.

\section{Introduction}

Weed infestation is a major yield-limiting factor for UK wheat production (Turley et al., 2003), in particular organic farming (Turner et al., 2007; Vijaya Bhaskar et al., 2014a). Tillage is one of the main methods to reduce weed pressure (Ozpinar, 2006), while it can also prepare an ideal seedbed for crop germination, growth and development (Gajri et al., 2002). Tillage often modifies weed abundance and species composition in crops by changing the seed distribution both vertically and horizontally; affecting the seeds viability, emergence and seedling survival (Chauhan, 2013; Håkansson, 2003). Tillage also dismembers vegetative structure of perennial weeds, and thereby stimulates bud growth and depletes their food reserves (Streit et al., 2002; Swanton et al., 2000). Due to this effect, ploughed soils commonly present a lower incidence of perennial grass weeds compared with less disturbed soils under reduced tillage (Demjanová et al., 2009). Inverting soil, however, can relocate buried seeds back to the topsoil (Colbach et al., 2006; Håkansson, 2003), often breaking seed dormancy and allowing seed germination, particularly of broadleaf weeds which have greater longevity and marked dormancy (Froud-Williams et al., 1983). Under reduced tillage 
practices, weed seeds are mostly left on the surface and distributed less down the soil profile due to reductions in soil disturbance, increasing germination and seedling survival of small seeded weeds (Ball, 1992; Nalewaja, 2001).

Development of herbicides has diminished the historic reliance on tillage systems for primary weed control (Nalewaja, 2001). However, a rising number of weeds resistant to a wide range of herbicide active ingredients have also been identified in the UK (Davies \& Finney, 2002), increasing interest in the complementary use of cultivation techniques and herbicide applications, towards a more integrated weed control strategy (Finch et al., 2014). For instance, the use of pre-crop emergence herbicides under reduced tillage controls weed seedlings at the soil surface (Calado et al., 2010). However, integration of tillage systems and herbicide can often alter herbicide's effectiveness for weed control, mainly related to soil residues cover intercepting the herbicide (Buhler, 1995; Chauhan, 2013; Vijaya Bhaskar et al., 2014b). Emphasising tillage influences on weed control is important in selecting an effective herbicide, with the associate costs also affecting profitability of the crop enterprise (Sayili et al., 2006).

Nitrogen (N) fertilisation modifies soil fertility directly, affecting not only crop growth but also weed density and composition (Jørnsgård et al., 1996; Yin et al., 2006). Weed growth can, however, also be indirectly influenced by $\mathrm{N}$ fertilisation by promoting faster growth of the crop, which in turn can increase crop competitiveness against weeds, resulting in the reduction of weed species number and biomass (Tang et al., 2013). Conversely, weed growth can response positively to $\mathrm{N}$ fertilisation possibly due to differential $\mathrm{N}$-use efficiently compared with the crop (Sheibani \& Ghadiri, 2012). Among weed species, N response also greatly differs (Yin et al., 2006). In a long-term experiment, Moss et al. (2004) reported that Stellaria media L. was highly favoured by N-rich conditions while other species, e.g. Medicago lupulina L., were highly disadvantaged. The aim of the current field experiments 
was to evaluate, within the scope of a transition from a long established organic farming system, contrasting tillage systems combined with different $\mathrm{N}$ fertilisation rates influences on weed infestation in the context of competitiveness and performance of spring wheat yield in a clay soil in the UK. Weed species composition, total weed biomass and prevalence were studied.

\section{Material and methods}

Site description

Field experiments were established from March to August 2013 and 2014 at the Royal Agricultural University's Harnhill Manor Farm, Cirencester, UK $\left(51^{\circ} 42^{\prime} \mathrm{N}, 01^{\circ} 59^{\prime} \mathrm{W}\right)$ at an altitude of $135 \mathrm{~m}$ above sea level. The land was managed organically since 1983 and the soil series (SSEW) was Evesham with a clay texture (23\% sand, $38 \%$ silt, $40 \%$ clay). Table 1 shows the initial soil physiochemical properties measured before the experiments were established (March 2013).

Figure 1 shows the monthly rainfall and mean temperatures during 2013 and 2014 growing seasons (March-August). Year-to-year variations in rainfall were observed over the study period. The total rainfall was 292 and $400.5 \mathrm{~mm}$ for 2013 and 2014, respectively. The mean total rainfall over the last 10 years was $377.2 \mathrm{~mm}$. The 2013 season was therefore a dry year, while 2014 was considered to be wet. Rainfall distribution also varied between years (Figure 1). In 2013, 63\% of the total season rainfall was recorded during spring months, particularly March and May, while in 2014 spring rainfall only counted for $50 \%$ of the total season rainfall. Temperature differed only slightly between seasons. Mean air temperature in 2013 of $11.7^{\circ} \mathrm{C}$, and in $2014,12.8^{\circ} \mathrm{C}$, were lower compared with the mean temperature over the last 10 years of $13.9^{\circ} \mathrm{C}$. 
Experimental design and treatment structure

Experiments followed a randomised complete block design in a split-plot arrangement replicated three times. Each block $(90 \mathrm{~m} \times 100 \mathrm{~m})$ was divided into three tillage treatments of $30 \mathrm{~m} \times 100 \mathrm{~m}$ (main plots) - Conventional plough-based Tillage (CT); High Intensity Noninversion Tillage (HINiT); and Low Intensity Non-inversion Tillage (LINiT). Details of the tillage treatments used are specified in Table 2. The amount of crop residues left on the soil surface were CT $0 \%$; HINiT $<30 \%$; and LINiT $>30 \%$.

Main plots were divided into four fully randomised split plots $(7.5 \mathrm{~m} \times 100 \mathrm{~m})$ of mineral nitrogen $(\mathrm{N})$ fertiliser application rates of $0(\mathrm{~N} 0), 70(\mathrm{~N} 70), 140$ (N140) and $210 \mathrm{~kg}$ $\mathrm{N}$ ha ${ }^{-1}(\mathrm{~N} 210)$. $\mathrm{N}$ fertiliser was applied as ammonium nitrate solution $(34.5 \% \mathrm{~N})$, with half rate applied at Zadoks, Chang \& Konzak decimal growth stage (GS) 13 and the remainder at GS 21 (Zadoks et al., 1974).

Spring wheat cv. Paragon was sown at a rate of 480 seeds $\mathrm{m}^{-2}$ on 10 April 2013 and 18 April 2014, and harvested on 27 August 2013 and 31 August 2014, respectively. Before the establishment of the experiments, the land was treated with systemic herbicide Roundup, a.i. glyphosate, at a rate of $4 \mathrm{~L} \mathrm{ha}^{-1}$ on 22 August 2012. Before primary cultivation operations (20 March 2013 and 24 March 2014), weeds were controlled again by glyphosate ( $2 \mathrm{~L} \mathrm{ha}^{-1}$ ) applied across all the plots.

Plant sampling

Weeds were hand-harvested using $0.25 \mathrm{~m}^{2}$ random quadrats for each split-plot with three replications. Dry weight (DM) yield was recorded after drying samples at $105^{\circ} \mathrm{C}$ overnight. Assessments were conducted on/before wheat GS31 (early assessment) and on/after GS61 (midseason assessment). At midseason assessment, weed species were separated and grouped 
accordingly to broadleaf and grass weeds. At crop maturity, spring wheat and weeds were hand-harvested using $0.25 \mathrm{~m}^{2}$ random quadrats for each split-plot with three replications, recovering all above ground plant material for analysis. Samples were dried at $105^{\circ} \mathrm{C}$ overnight and DM recorded. Ears were threshed by hand and the amount of grain was weighed to obtain grain yield, which was subsequently corrected to $15 \%$ moisture content.

Statistical analysis

Statistical analyses were performed using the split-plot analysis of variance (ANOVA) model in Genstat $\left(15^{\text {th }}\right.$ Edition VSN International Ltd, Hemel Hempstead, UK) using Fisher's protected least significant difference at $P<0.05$. Uniformity of variance and residuals of all the data sets were verified before reporting results.

\section{Results}

Season effect on weed biomass and spring wheat yield

Weed biomass significantly varied between the seasons (Table 3). Early weed DM was significantly higher in 2014 compared with 2013, while midseason total weed biomass and broadleaf weed DM were significantly higher in 2013 than in 2014. Grass weed DM was not significantly influenced by year. At harvest, total weed biomass and spring wheat grain yield were significantly higher in 2013 compared to 2014 (Table 3).

Influence of tillage on weed biomass and wheat grain yield production Early weed DM was significantly affected by tillage, with HINiT resulting in higher biomass compared to CT and LINiT (Table 3). There was a significant year $\times$ tillage interaction affecting early weed DM (Table 3). In 2014, HINiT resulted in higher early weed DM 
compared to LINiT and CT, while in 2013 differences between tillage systems were reduced (Figure 2). At midseason, HINiT resulted in significantly higher total weed DM and broadleaf weed DM compared to LINiT, followed by CT (Table 3). CT resulted in lower midseason weed DM and broadleaf weed biomass in 2014 than in 2013, while no differences were observed between years on HINiT and LINiT (Figure 2). Grass weed DM was significantly higher under HINiT and LINiT than under CT (Table 3). Total weed biomass at harvest was significantly affected by tillage and year $\times$ tillage interaction effect, resulting in higher DM under HINiT and LINiT compared to CT across both years (Table 3; Figure 2). Spring wheat grain yield was significantly affected by tillage and year $\mathrm{x}$ tillage interaction (Table 3). Significant higher grain yield was produced by CT than LINiT and followed by HINiT (Table 3). In 2013, grain yields under LINiT were higher than HINiT and statistically similar to those under CT, while in 2014 CT resulted in higher grain yield than HINiT and LINiT (Figure 2).

Influence of $\mathrm{N}$ management on weed biomass and wheat grain yield production $\mathrm{N}$ fertilisation did not significantly affect early weed biomass (Table 3 ). Total midseason and broadleaf weed DM was significantly lower under unfertilised conditions compared to any $\mathrm{N}$ rate applied (Table 3). Grass weed DM was higher at high rates of $\mathrm{N}$ applied, such as 140 and $210 \mathrm{~kg} \mathrm{~N} \mathrm{ha}^{-1}$, compared to lower $\mathrm{N}$ rates (Table 3). $\mathrm{N}$ fertilisation significantly affected total weed DM at harvest and spring wheat grain yield (Table 3). Lower weed DM at harvest was observed under unfertilised conditions than when $\mathrm{N}$ was applied. Grain yield ranged from 4.25 to $5.02 \mathrm{t} \mathrm{ha}^{-1}$ as affected by $\mathrm{N}$ fertilisation, with higher yield produced with application of 140 and $210 \mathrm{~kg} \mathrm{~N} \mathrm{ha}^{-1}$ (Table 3). 
Influence of tillage and $\mathrm{N}$ management on weed biomass and specie composition

Total midseason and broadleaf weed biomass, and total weed DM at harvest were significantly higher under HINiT and LINiT when $\mathrm{N}$ fertilisation was applied compared to unfertilised conditions, while under CT there was not response to N supply (Figure 3).

A total of 39 weed species were recorded in 2013, and 29 species in 2014, irrespectively of management treatments. Only the dominant weed species - listed in Table 4 - were significantly affected by the management practices, while other species were not significantly affected or occurred too infrequently to permit treatment effects to be appropriately tested.

There was a significant year effect on all dominant weed species (Table 5). In 2013, Stellaria media, Fallopia convolvulus, Lolium perenne, and Avena fatua biomass was significantly higher than in 2014, while Sinapsis arvensis, Galium aparine and Avena sativa DM was higher in 2014 than in 2013 (Table 5). Significant tillage effects on all dominant weed species were observed except on Avena spp. Stellaria media and Sinapsis arvensis biomass was higher under HINiT compared with CT and LINiT (Table 5). Fallopia convolvulus and Lolium perenne biomass was significantly higher under LINiT compared to HINiT and CT, while Galium aparine DM was significantly higher under LINiT than HINiT, followed by CT (Table 5).

Stellaria media DM was higher under CT and HINiT in 2013 than in 2014, while no differences between years were observed under LINiT (Figure 4). Sinapsis arvensis DM under HINiT was significantly higher in 2014 compared to 2013, while under LINiT and CT no differences were observed across seasons. Under LINiT, Lolium perenne biomass was higher in 2013 than in 2014. No differences across years were observed in Lolium perenne DM under CT and HINiT (Figure 4). 
$\mathrm{N}$ management and tillage $\times \mathrm{N}$ fertilisation interaction significantly affected Stellaria media and Sinapsis arvensis biomass (Table 5). Higher Stellaria media DM was produced when $70 \mathrm{~kg} \mathrm{~N} \mathrm{ha}^{-1}$ was applied, particularly when compared to unfertilised conditions and to $210 \mathrm{~kg} \mathrm{~N} \mathrm{ha}{ }^{-1}$ applied (Table 5). Under HINiT, application of 70 and $140 \mathrm{~kg} \mathrm{~N} \mathrm{ha}{ }^{-1}$ significantly increased Stellaria media DM, while no significant interactions were observed under CT and LINiT (Figure 5a). Sinapsis arvensis DM increased when N was applied compared to unfertilised plots (Table 5). Year $\times \mathrm{N}$ management interaction significantly affected Sinapsis arvensis DM, resulting a higher response to N application, particularly when high $\mathrm{N}$ rates were applied, in 2014 compared to 2013 (Figure 4). Under HINiT, Sinapsis arvensis growth was significantly increased when $\mathrm{N}$ was applied compared to unfertilised conditions, while no differences were observed under LINiT and CT (Figure 5a). Lolium perenne DM was significantly higher in 2013 when $140 \mathrm{~kg} \mathrm{~N} \mathrm{ha}^{-1}$ was applied, while in 2013 there were not differences (Figure 4). Significant increase of Lolium perenne DM was also observed in 2013 under LINiT and when high $\mathrm{N}$ rates were applied (Figure 5b).

\section{Discussion}

Season effect on weed biomass and spring wheat yield

High weed prevalence, and its negative impacts on organic cereal crop performance on this field site have previously been reported (Cosser et al., 1996a,b, 1997; Vijaya Bhaskar et al., $2014 a, b$ ). To overcome this challenge, a pre-cultivation herbicide glyphosate was applied across the experimental site on both 2013 and 2014 seasons. However, the legacy of high weed pressure from the formerly organic management resulted in greater weed prevalence in 2013, following the herbicide application and dry weather conditions. In contrast, 2014 was the second year with herbicide inclusion exerting greater effect on controlling weeds at 
harvest compared with 2013. Travlos (2012) observed a reduction on weed biomass after two crop seasons with application of herbicide as a result of significant reduction of produced seed in the first year after herbicides. Season conditions also affected tillage systems effects on weed biomass and prevalence. The continuity of herbicide inclusion in 2014 appears to have reduced weed biomass under CT when compared with 2013, while similar HINiT and LINiT effects between the two cropping seasons suggests that higher herbicide rates are perhaps needed under reduced tillage, as reported by Bostrom et al. (2000).

Weed biomass growth varied as the growing season progress. Increases on weed biomass growth from early to midseason assessments were mainly related to weed community grow, while as the season progress towards harvest there was a natural decay of their biomass. Jørnsgård et al. (1996) also reported differences on weed biomass from germination till the end of the growing season.

Higher spring wheat grain yield in the 2013 dry year than in 2014 wet shows that weeds were not the only yield-limiting factor, as the year with the highest weed prevalence coincided with the highest yield, i.e. 2013. Similarly, lower yield under HINiT and LINiT in 2014 compared with 2013 was observed despite lower weed prevalence in 2014. Gruber et al. (2012) also reported that even though a high weed density was observed there was no evidence that weeds alone were restricting main crop yield. Wheat yield was, therefore, the result of complex interactions between seedbed conditions, weed pressure and weather conditions (Rial Lovera, 2015).

Influence of tillage on weed biomass and wheat grain yield production

The current study shows that the effectiveness of tillage in controlling weeds is also much influenced understandably by weather conditions across the seasons. Under relatively warm and drier conditions experienced in 2013, the tillage relevance in controlling early weed 
growth was reduced, while higher early weed growth in 2014 seems to be related to higher rainfall conditions in April. Fernández-Getino et al. (2015) reported that increased rainfall was positively correlated with increases in weed biomass. Under those cold and wet conditions in 2014 inverting the soil with CT resulted in the lowest early weed DM as also reported by Fernández-Getino et al. (2015). Under HINiT, lower plant residue cover and increasing soil disturbance compared with LINiT, may have allowed drier and warmer soil conditions encouraging more weed germination. This is an assumption, however, as soil conditions and weeds proportions may have been compensating, as suggested by Colbach et al. (2006).

Although, the approach employed for the herbicide application did not allow the specific impact on weed dynamics to be tested, it is possible to speculate on its relative effect on weed occurrence. Mavunganidze et al. (2014) reported that a broad-spectrum herbicide such as glyphosate controls both grass and broadleaf weed species. In the present study, however, grass weed biomass was lower compared with broadleaf weeds following herbicide application, as reported elsewhere (Ewald \& Aebischer, 2000; Marshall \& Nowakowski, 1996).

Broadleaf weeds mainly accounted for differences between tillage treatments in the total weed DM, as Demjanová et al. (2009) also reported. This was observed as HINiT resulted in higher total weed and broadleaf weeds DM than LINiT and CT. Clements et al. (1996) and Swanton et al. (2000) also reported greater incidence of this weed group under reduced tillage. Due to rainfall conditions, crop sowing operations were slightly later in both years, which could have allowed the emergence, after herbicide application, of the weeds retained in soil under non-inversion tillage. This condition combined with increases in soil disturbance intensity is the possible reason for high biomass of short-lived annual broadleaf weeds under HINiT. Higher presence of soil residue cover under LINiT can create 
shadowing, reducing germination of broadleaf species after herbicide application (Teasdale et al., 1991). Grass weed DM was higher under HINiT and LINiT, as this weed group is highly affected by intensive soil mechanical disturbance, especially ploughing (Demjanová et al., 2009; Streit et al., 2002).

Weed prevalence at harvest was promoted by non-inversion tillage treatments in both years compared with CT. Weeds that escaped foliar contact herbicide were likely to grow, but the subsequent soil inversion under $\mathrm{CT}$ is thought to have reduced weed presence across the seasons, as also reported elsewhere (e.g. Nakamoto et al., 2006; Santín-Montanyá et al., 2013). This situation also provided a head-start for the crop, such that it can effectively compete with later-emerging weeds.

Spring wheat grain yield was higher under CT showing an inverse relationship between lower weed prevalence and crop performance. Others (e.g. (Gruber et al., 2012; Yagioka et al., 2015; Fernández-Getino et al., 2015) also reported that lower weed pressure under CT can be one of the factors allowing higher grain yields compared with reduced tillage practices. Wheat yield under LINiT, however, was higher than under HINiT despite similar weed prevalence observed. This confirms, as expected, that weed pressure is not the only yield- limiting factor under reduced tillage systems, as also reported by Gruber et al. (2012).

Influence of $\mathrm{N}$ management on weed biomass and wheat grain yield production $\mathrm{N}$ fertilisation significantly increased midseason total weed DM, and weed prevalence at harvest which is consistent with others (e.g. Blackshaw et al., 2005; Lal et al., 2014). N fertilisation caused shifts in weed species, with grass weeds more advantaged under N-rich conditions in both years, while broadleaf weeds biomass increased when $\mathrm{N}$ was applied regardless of rate. However, broadleaf weeds were more relevant than grass weeds, showing higher weed biomass as Maskell et al. (2010) and Storkey et al. (2011) have also reported. 
Weed growth as affected by $\mathrm{N}$ application appears to have not affected final grain yield particularly at higher $\mathrm{N}$ rates, as both crop yield and weeds biomass increased with $\mathrm{N}$, as also reported by Jørnsgård et al. (1996) and O’Donovan et al. (1997). At lower N rates, however, weed prevalence can be one of the factors reducing grain yield, as observed when $70 \mathrm{~kg} \mathrm{~N} \mathrm{ha}{ }^{-1}$ was applied. Under unfertilised conditions, grain yield is likely to be more influenced by lower $\mathrm{N}$ availability than by weed presence. These results suggests that rich $\mathrm{N}$ fertilisation can potentially increase crop competitiveness against weeds, as other reported (Tang et al., 2013; Sheibani \& Ghadiri, 2012).

Influence of tillage and $\mathrm{N}$ management on weed biomass and specie composition The application of $\mathrm{N}$ fertiliser under HINiT and LINiT produced an increase on broadleaf weed biomass, total midseason biomass and weed prevalence at harvest. This is the result of favourable conditions under reduced tillage allowing weed seed germination and $\mathrm{N}$ promoting weed growth, as also observed by Małecka \& Blecharczyk (2008).

Most of the weeds species identified are commonly report in spring wheat production (HGCA, 2010) and their presence was influenced by the agricultural managements adopted and time of assessment as reported by Menalled et al. (2001). However, species composition in crops is also primarily influenced by weather conditions across seasons (Håkansson, 2003; Shrestha et al., 2002). Stellaria media and Sinapsis arvensis DM was higher under N-rich conditions and when combined with HINiT, as others reported (e.g. Moss et al., 2004; Ozpinar, 2006). However, the wet conditions observed in 2014 could have possibly reduced soil N availability, increasing the response of Sinapsis arvensis when N was applied, while no $\mathrm{N}$ fertilisation effect was observed in 2013 dry season.

The increase of Fallopia convolvulus and Galium aparine DM under LINiT is perhaps the result of less competition with other dominant weed species which were more common 
under HINiT. Seedbed conditions under LINiT were more advantageous for Lolium perenne to grow than under HINiT and CT, as this grass is more susceptible to mechanical disturbance of soil (Håkansson, 2003; Tuesca \& Puricelli, 2007). Additionally, the fast growth behaviour of Lolium perenne requires high $\mathrm{N}$ supply (Daepp et al., 2001), which resulted in higher biomass production under LINiT when combined with $\mathrm{N}$ fertilisation in 2013. Its lower DM in 2014 seems, however, to have offset effects of the management practices.

\section{Conclusions}

Although weed community response to tillage was specific to year-to year weather and soil conditions, some overall conclusions are possible. Conventional plough-based tillage (CT) controls weeds better. In contrast, High Intensity Non-Inversion Tillage (HINiT) promotes infestations by broadleaf weed species rapidly increasing the total weed biomass, even when broad-spectrum herbicide is applied. This disadvantage can negatively affect wheat production. Hence, rotational use of reduced tillage practices, such as Low Intensity Noninversion Tillage, into CT systems may be a practical way to increase their adoption for more sustainable cereal production. The risk of increased weed pressure when applying $\mathrm{N}$ fertilisation can be reduced by lowered $\mathrm{N}$ rates in the field.

\section{Acknowledgement}

Financial support from the Royal Agricultural University for the studentship is greatly acknowledged. 


\section{References}

Ball D.A. (1992) Weed seed bank response to tillage, herbicide and crop rotation sequence. Weed Science, 40, 654-659.

Blackshaw R.E., Molnar L.J., Larney F.J. (2005) Fertilizer, manure and compost effects on weed growth and competition with winter wheat in western Canada. Crop Protection, 24, 971-980.

Bostrom U., Hansson M., Fogelfors H. (2000) Weeds and yields of spring cereals as influenced by stubble- cultivation and reduced doses of herbicides in five long-term trials. Journal of Agricultural Science, 134, 237-244.

Buhler D.D. (1995) Influence of tillage systems on weed population dynamics and management in corn and soybean in the central USA. Crop Science, 35, 1247-1258.

Calado J.M.G., Basch G., de Carvalho M. (2010) Weed management in no-till winter wheat (Triticum aestivum L.). Crop Protection, 29, 1-6.

Chauhan B.S. (2013) Effect of tillage systems, seeding rates, and herbicides on weed growth and grain yield in dry-seeded rice systems in the Philippines. Crop Protection, 54, 244 250.

Clements D.R., Benott D.L., Murphy S.D., Swanton C.J. (1996) Tillage effects on weed seed return and seed bank composition. Weed Science, 44, 314-322.

Colbach N., Busset H., Yamada O., Dürr C., Caneill J. (2006) AlomySys: Modelling blackgrass (Alopecurus myosuroides Huds.) germination and emergence, in interaction with seed characteristics, tillage and soil climate: II. Evaluation. European Journal of Agronomy, 24, 113-128.

Cosser N.D., Gooding M.J., Davies W.P., Froud-Williams R.J. (1996a) Effects of wheat dwarfing genes on grain yield and quality of wheat in comparison with Alopecurus 
myosuroides. In Second International Weed Control Congress, pp. 1089-1094.

Copenhagen.

Cosser N.D., Gooding M.J., Froud-Williams R.J. (1996b) The impact of wheat cultivar, sowing date and grazing on the weed seedbank of an organic farming system. Aspects of Applied Biology 47, Rotations and Cropping Systems, pp. 197-200.

Cosser N.D., Gooding M.J., Thompson A.J., Froud-Williams R.J. (1997) Competitive ability and tolerance of organically grown wheat cultivars to natural weed infestations. Annals of Applied Biology, 130, 523-535.

Daepp M., Nösberger J., Lüscher A. (2001) Nitrogen fertilization and developmental stage alter the response of Lolium perenne to elevated CO2. New Phytologist, 150, 347-358.

Davies D.B., Finney J.B. (2002) Reduced cultivations for cereals: Research, development and advisor needs under changing economic circumstances. London, UK: Home-Grown Cereals Authority (HGCA).

Demjanová E., Macák M., Dalovic I., Majerník F., Týr Š., Smatana J. (2009) Effects of tillage systems and crop rotation on weed density, weed species composition and weed biomass in maize. Agronomy Research, 7, 785-792.

Ewald J.A., Aebischer N.J. (2000) Trends in pesticide use and efficacy during 26 years of changing agriculture in southern England. Environmental Monitoring and Assessment, 64, 439-529.

Fernández-Getino A.P., Santín-Montanyá M.I., Zambrana E., de Andrés E.F., Tenorio J.L. (2015) The response of barley to rainfall and temperature in different tillage and crop rotation systems in semi-arid conditions. Annals of Applied Biology, 166, 143-153.

Finch H.J.S., Samuel A.M., Lane G.P.F. (Eds). (2014) Lockhart \& Wiseman's Crop husbandry including grassland, $9^{\text {th }}$ Edn. Woodhead Publishing series in Food Science, Technology and Nutrition. 
Froud-Williams R.J., Drennan D.S.H., Chancellor R.J. (1983) Influence of cultivation regime on weed floras of arable cropping systems. Source Journal of Applied Ecology Journal of Applied Ecology, 20, 187-197.

Gajri P.R., Arora V.K., Prihar S.S. (2002) Tillage for Sustainable Cropping. New York: Food Press.

Gruber S., Pekrun C., Möhring J., Claupein W. (2012) Long-term yield and weed response to conservation and stubble tillage in SW Germany. Soil and Tillage Research, 121, 49-56.

Håkansson S. (2003) Weeds and weed management on arable land: an ecological approach. Wallingford: CABI Publising.

HGCA (2010) Managing weeds in arable rotations - a guide. London, UK: Home-Grown Cereals Authority (HGCA).

Jørnsgård B., Rasmussen K., Hill J., Christiansen J.L. (1996) Influence of nitrogen on competition between cereals and their natural weed populations. Weed Research, 36, 461-470.

Lal B., Gautam P., Raja R., Nayak A.K., Shahid M., Tripathi R., Bhattacharyya P., Mohanty S., Puri C., Kumar A., Panda B.B. (2014) Weed community composition after 43 years of long-term fertilization in tropical rice-rice system. Agriculture, Ecosystems \& Environment, 197, 301-308.

Małecka I., Blecharczyk A. (2008) Effect of tillage systems, mulches and nitrogen fertilization on spring barley (Hordeum vulgare). Agronomy Research, 6, 517-529.

Marshall E.J.P., Nowakowski M. (1996) Interactions between cutting and a graminicide on a newly-sown grass and wild flower field margin strip. Aspect of Applied Biology, 44, 307-312. 
Maskell L.C., Smart S.M., Bullock J.M., Thompson K.E.N., Stevens C.J. (2010) Nitrogen deposition causes widespread loss of species richness in British habitats. Global Change Biology, 16, 671-679.

Mavunganidze Z., Madakadze I.C., Nyamangara J., Mafongoya P. (2014) The impact of tillage system and herbicides on weed density, diversity and yield of cotton (Gossipium hirsutum L.) and maize (Zea mays L.) under the smallholder sector. Crop Protection, 58, $25-32$.

Menalled F.D., Gross K.L., Hammond M. (2001) Weed Aboveground and Seedbank Community Responses to Agricultural Management Systems. Source: Ecological Applications, 11, 1586-1601. Available at: http://www.jstor.org/stable/3061080.

Moss S., Storkey J., Cussans J.W., Perryman S.A.M., Hewitt M. V. (2004) The Broadbalk long-term experiment at Rothamsted: what has it told us about weeds? Weed Science, 52, 864-873.

Nakamoto T., Yamagishi J., Miura F. (2006) Effect of reduced tillage on weeds and soil organisms in winter wheat and summer maize cropping on Humic Andosols in Central Japan. Soil and Tillage Research, 85, 94-106.

Nalewaja J.D. (2001) Weeds and Conservation Agriculture, In Conservation Agriculture, A Worldwide Challenge. I World Congress on Conservation Agriculture, Volume I: Keynote Contributions., pp. 191-200. Eds L. Garcia-Torres, J. Benites, and A. MartinezVilela. Cordoba, Spain: XUL.

O’Donovan J.T., McAndrew D.W., Thomas A.G. (1997) Tillage and nitrogen influence weed population dynamics in barley (Hordeum vulgare). Weed Technology, 11, 502-509.

Ozpinar S. (2006) Effects of tillage systems on weed population and economics for winter wheat production under the Mediterranean dryland conditions. Soil and Tillage Research, 87, 1-8. 
Rial Lovera K.E. (2015) Evaluation of cultivation, legume undersowing and nitrogen interventions on wheat development. Ph.D. dissertation. Coventry University, UK.

Santín-Montanyá M.I., Martín-Lammerding D., Walter I., Zambrana E., Tenorio J.L. (2013) Effects of tillage, crop systems and fertilization on weed abundance and diversity in 4year dry land winter wheat. European Journal of Agronomy, 48, 43-49.

Sayili M., Akca H., Önen H. (2006) Economic analysis of herbicide usage in wheat fields. Journal of Plant Diseases and Protection, XX, 755-760.

Sheibani S., Ghadiri H. (2012) Integration effects of split nitrogen fertilization and herbicide application on weed management and wheat yield. Journal of Agricultural Science and Technology, 14, 77-86.

Shrestha A., Knezevic S.Z., Roy R.C., Ball-Coelho B.R., Swanton C.J. (2002) Effect of tillage, cover crop and crop rotation on the composition of weed flora in a sandy soil. Weed Research, 42, 76-87.

Storkey J., Meyer S., Still K.S., Leuschner C. (2011) The impact of agricultural intensification and land-use change on the European arable flora. Proceedings of the Royal Society B, 279, 1421-1429.

Streit B., Rieger S.B., Stamp P., Richner W. (2002) The effect of tillage intensity and time of herbicide application on weed communities and populations in maize in central Europe. Agriculture, Ecosystems and Environment, 92, 211-224.

Swanton C.J., Shrestha A., Knezevic S.Z., Roy R.C., Ball-Coelho B.R. (2000) Influence of tillage type on vertical weed seedbank distribution in a sandy soil. Canadian Journal of Plant Science, 80, 455-457.

Tang L., Wan K., Cheng C., Li R., Wang D., Pan J., Tao Y., Xie J., Chen F. (2013) Effect of fertilization patterns on the assemblage of weed communities in an upland winter wheat field. Journal of Plant Ecology, 1-12. 
Teasdale J.R., Beste C.E., Potts W.E. (1991) Response to weeds to tillage and cover crop residue. Weed Science, 39, 195-199.

Travlos I.S. (2012) Reduced herbicide rates for an effective weed control in competitive wheat cultivars. International Journal of Plant Production, 6, 1-14.

Tuesca D., Puricelli E. (2007) Effect of tillage systems and herbicide treatments on weed abundance and diversity in a glyphosate resistant crop rotation. Crop Protection, 26, $1765-1770$.

Turley D.B., Phillips M.C., Johnson P., Jones A.E., Chambers B.J. (2003) Long-term straw management effects on yields of sequential wheat (Triticum aestivum L.) crops in clay and silty clay loam soils in England. Soil and Tillage Research, 71, 59-69.

Turner R.J., Davies G., Moore H., Grundy A.C., Mead A. (2007) Organic weed management: A review of the current UK farmer perspective. Crop Protection, 26, 377-382.

Vijaya Bhaskar A.V., Davies W.P., Cannon N.D., Conway J.S. (2014a) Weed manifestation under different tillage and legume undersowing in organic wheat. Biological Agriculture \& Horticulture, 125, 129-134.

Vijaya Bhaskar A.V., Rial Lovera K., Davies W.P., Cannon N.D. (2014b) Weed prevalence under organic and low input cultivation systems, In Aspects of Applied Biology 125, Agronomic decision making in an uncertain climate, pp. 129-134.

Yagioka A., Komatsuzaki M., Kaneko N., Ueno H. (2015) Effect of no-tillage with weed cover mulching versus conventional tillage on global warming potential and nitrate leaching. Agriculture, Ecosystems \& Environment, 200, 42-53.

Yin L., Cai Z., Zhong W. (2006) Changes in weed community diversity of maize crops due to long-term fertilization. Crop Protection, 25, 910-914.

Zadoks J.C., Chang T.T., Konzak C.F. (1974) A decimal code for the growth stages of cereals. Weed Research, 14, 415-421. 
Table 1. Key topsoil characteristics $(0-25 \mathrm{~cm})$

\begin{tabular}{lc|lc}
\hline Parameter & Value & Parameter & Value \\
\hline SMN $\left(\mathrm{kg} \mathrm{ha}^{-1}\right)$ & 25.3 & $\mathrm{P}\left(\mathrm{mg} \mathrm{l}^{-1}\right)$ & 8.0 \\
pH (water) & 6.9 & $\mathrm{~K}\left(\mathrm{mg} \mathrm{l}^{-1}\right)$ & 208.7 \\
Organic matter $(\%)$ & 4.7 & ${\mathrm{Mg}\left(\mathrm{mg} \mathrm{l}^{-1}\right)}$ & 105.3 \\
\hline
\end{tabular}

Table 2. Specifications of the tillage treatments adopted in 2013 and 2014

\begin{tabular}{|c|c|c|}
\hline & Primary cultivation & Secondary cultivation \\
\hline $\mathrm{CT}$ & $\begin{array}{l}\text { Five furrow Kverneland reversible } \\
\text { plough }(20 \mathrm{~cm})\end{array}$ & $\begin{array}{c}\text { Kuhn power harrow combination seed } \\
\text { drill }(8 \mathrm{~cm})\end{array}$ \\
\hline HINiT & $\begin{array}{l}\text { ST bar attached to Simba X-press } \\
(25 \& 12 \mathrm{~cm})(2 \text { passes })\end{array}$ & $\begin{array}{l}\text { Vaderstad Rapid-A system disc } \\
\text { combination seed drill }(8 \mathrm{~cm})\end{array}$ \\
\hline LINiT & $\begin{array}{l}\text { ST bar attached to Simba X-press } \\
\qquad(25 \& 12 \mathrm{~cm})(1 \text { pass })\end{array}$ & Eco-dyn integrated seed drill $(26 \mathrm{~cm})$ \\
\hline
\end{tabular}


Table 3. Analysis of variance for year, tillage and $\mathrm{N}$ management effects. Mean values for weed aboveground biomass and spring wheat grain yield parameter

\begin{tabular}{|c|c|c|c|c|c|c|c|}
\hline Source & df & $\begin{array}{c}\text { Early total } \\
\text { weed } \\
\text { DM }\left(\mathrm{t} \mathrm{ha}^{-1}\right)\end{array}$ & $\begin{array}{l}\text { Midseason } \\
\text { total weed } \\
\text { DM }\left(\mathrm{t} \mathrm{ha}^{-1}\right)\end{array}$ & $\begin{array}{c}\text { Broadleaf } \\
\text { weed } \\
\text { DM }\left(\mathrm{t} \mathrm{ha}^{-1}\right)\end{array}$ & $\begin{array}{c}\text { Grass } \\
\text { weed DM } \\
\left(\mathrm{t} \mathrm{ha}^{-1}\right)\end{array}$ & $\begin{array}{c}\text { Total weed } \\
\mathrm{DM}\left(\mathrm{t} \mathrm{ha}^{-1}\right) \\
\text { at harvest }\end{array}$ & $\begin{array}{l}\text { Grain yield } \\
\quad\left(\mathrm{t} \mathrm{ha}^{-1}\right)\end{array}$ \\
\hline Year (Y) & 1 & & & & & & \\
\hline 2013 & & $0.0338 \mathrm{a}$ & $1.438 b$ & $1.131 \mathrm{~b}$ & $0.307 \mathrm{a}$ & $1.140 \mathrm{~b}$ & $5.595 b$ \\
\hline 2014 & & $0.0837 b$ & $1.138 \mathrm{a}$ & $0.816 \mathrm{a}$ & $0.321 \mathrm{a}$ & $0.905 \mathrm{a}$ & $3.701 \mathrm{a}$ \\
\hline$S E D$ & & $0.01069 * * *$ & $0.0915 * * *$ & $0.0700 * * *$ & $0.0697^{n s}$ & $0.0850 * *$ & $0.1469 * * *$ \\
\hline Tillage (T) & 2 & & & & & & \\
\hline $\mathrm{CT}$ & & $0.0198 \mathrm{a}$ & $0.528 \mathrm{a}$ & $0.4468 \mathrm{a}$ & $0.0812 \mathrm{a}$ & $0.507 \mathrm{a}$ & $5.473 \mathrm{c}$ \\
\hline HINiT & & $0.1186 b$ & $1.953 \mathrm{c}$ & $1.5921 \mathrm{c}$ & $0.3612 b$ & $1.301 \mathrm{~b}$ & $3.833 \mathrm{a}$ \\
\hline LINiT & & $0.0378 \mathrm{a}$ & $1.382 b$ & $0.8821 b$ & $0.5004 b$ & $1.259 \mathrm{~b}$ & $4.638 b$ \\
\hline$S E D$ & & $0.01309 * * *$ & $0.1121 * * *$ & $0.0857 * * *$ & $0.0854 * * *$ & $0.1041 * * *$ & $0.1800 * * *$ \\
\hline $\mathrm{N}$ rate $(\mathrm{N})$ & 3 & & & & & & \\
\hline N0 & & $0.0559 a$ & $0.661 \mathrm{a}$ & $0.5581 \mathrm{a}$ & $0.1024 a$ & $0.715 \mathrm{a}$ & $4.248 \mathrm{a}$ \\
\hline N70 & & $0.0694 \mathrm{a}$ & $1.427 \mathrm{~b}$ & $1.1963 b$ & $0.2310 \mathrm{a}$ & $1.193 b$ & $4.381 \mathrm{a}$ \\
\hline N140 & & $0.0553 \mathrm{a}$ & $1.543 b$ & $1.1079 b$ & $0.4348 b$ & $1.087 \mathrm{~b}$ & $4.945 b$ \\
\hline $\mathrm{N} 210$ & & $0.0544 \mathrm{a}$ & $1.521 \mathrm{~b}$ & $1.0323 b$ & $0.4888 b$ & $1.094 \mathrm{~b}$ & $5.019 \mathrm{~b}$ \\
\hline$S E D$ & & $0.01511^{n s}$ & $0.1294 * * *$ & $0.0990 * * *$ & $0.0986 * * *$ & $0.1202 * * *$ & $0.2078 * * *$ \\
\hline $\mathrm{Y} \times \mathrm{T}$ & 2 & $0.01851 * * *$ & $0.1585^{*}$ & $0.1212 * *$ & $0.1208^{n s}$ & $0.1472 * * *$ & $0.2545 * * *$ \\
\hline $\mathrm{Y} \times \mathrm{N}$ & 3 & $0.02137^{n s}$ & $0.1831^{n s}$ & $0.1400^{n s}$ & $0.1395^{n s}$ & $0.1699^{n s}$ & $0.2939^{n s}$ \\
\hline $\mathrm{T} \times \mathrm{N}$ & 6 & $0.02618^{n s}$ & $0.2242 * * *$ & $0.1714 * * *$ & $0.1708^{n s}$ & $0.2081 *$ & $0.3599^{n s}$ \\
\hline $\mathrm{Y} \times \mathrm{T} \times \mathrm{N}$ & 6 & $0.03702^{n s}$ & $0.3171^{n s}$ & $0.2424^{n s}$ & $0.2416^{n s}$ & $0.2943^{n s}$ & $0.5090^{n s}$ \\
\hline
\end{tabular}

Values are mean; df, degree of freedom; and SED (in italics), Standard errors of difference for treatments and treatments interactions.

Values followed by same letter, do not differ significantly at $P<0.05 ; *=P<0.05$, **= $P<0.01 ; * * *=P<0.001$; and $n s=$ not significant. 


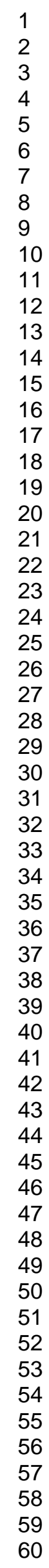 \\ Page 23 of 32}

1

2

4

5

7

8

10

11
12

13

14

15

16

18

19

20

22

23

25

26

28

30

31

33

34

36

37

38

39

40

41

43

44

45

46

47

48

49

51

52

54

55

57

58

60 
Table 4. Ranking of dominant weed species by contribution to the total midseason weed biomass in 2013 and 2014

\begin{tabular}{|c|c|c|c|c|c|c|}
\hline \multirow{2}{*}{ Rank } & \multicolumn{3}{|l|}{2013} & \multicolumn{3}{|l|}{2014} \\
\hline & Weed species & Code $\mathrm{EPPO}^{\mathrm{a}}$ & Contribution $^{\mathrm{b}}$ & Weed species & Code $\mathrm{EPPO}^{\mathrm{a}}$ & Contribution $^{\mathrm{b}}$ \\
\hline 1 & Stellaria media (L.) Vill. & STEMM & $29.8 \%$ & Sinapsis arvensis (L.) & SINAR & $35.1 \%$ \\
\hline 2 & Fallopia convolvulus (L.) & POLCO & $12.1 \%$ & Avena sativa (L.) & AVESA & $26.9 \%$ \\
\hline 3 & Avena fatua (L.) & AVEFA & $11.9 \%$ & Stellaria media (L.) Vill. & STEMM & $15.2 \%$ \\
\hline 4 & Sinapsis arvensis (L.) & SINAR & $9.7 \%$ & Galium aparine (L.) & GALHM & $14.8 \%$ \\
\hline 5 & Lolium perenne (L.) & LOLPE & $8.1 \%$ & Lolium perenne (L.) & LOLPE & $2.0 \%$ \\
\hline
\end{tabular}

${ }^{\mathrm{b}}$ Contribution (\%) of the weed specie DM to the midseason total weed DM in each year. 
Table 5. Analysis of variance for year, tillage and $\mathrm{N}$ management effects. Mean values for dominant weed species biomass parameter

\begin{tabular}{|c|c|c|c|c|c|c|c|c|}
\hline Source & df & $\begin{array}{c}\text { Stellaria } \\
\text { media }\end{array}$ & $\begin{array}{l}\text { Sinapsis } \\
\text { arvensis }\end{array}$ & $\begin{array}{c}\text { Fallopia } \\
\text { convolvulus }\end{array}$ & $\begin{array}{l}\text { Galium } \\
\text { aparine }\end{array}$ & $\begin{array}{l}\text { Lolium } \\
\text { perenne }\end{array}$ & $\begin{array}{l}\text { Avena } \\
\text { fatua }\end{array}$ & $\begin{array}{l}\text { Avena } \\
\text { sativa }\end{array}$ \\
\hline Year (Y) & 1 & & & & & & & \\
\hline 2013 & & $0.425 b$ & $0.138 \mathrm{a}$ & $0.173 b$ & $0.082 \mathrm{a}$ & $0.1161 b$ & $0.170 \mathrm{~b}$ & $0.0004 \mathrm{a}$ \\
\hline 2014 & & $0.167 \mathrm{a}$ & $0.385 b$ & $0.037 \mathrm{a}$ & $0.162 b$ & $0.0220 \mathrm{a}$ & $0.0001 \mathrm{a}$ & $0.0061 b$ \\
\hline SED & & $0.0379 * * *$ & $0.0484 * * *$ & $0.0237 * * *$ & $0.0320 *$ & $0.01660 * * *$ & $0.0460 * * *$ & $0.00263 *$ \\
\hline Tillage (T) & 2 & & & & & & & \\
\hline $\mathrm{CT}$ & & $0.1166 a$ & $0.1263 a$ & $0.0579 a$ & $0.0046 a$ & $0.00791 \mathrm{a}$ & $0.035 \mathrm{a}$ & $0.0001 \mathrm{a}$ \\
\hline HINiT & & $0.5952 b$ & $0.5530 \mathrm{~b}$ & $0.0876 \mathrm{a}$ & $0.1276 b$ & $0.01885 a$ & $0.137 \mathrm{a}$ & $0.0074 \mathrm{a}$ \\
\hline LINiT & & $0.1763 a$ & $0.1053 a$ & $0.1690 \mathrm{~b}$ & $0.2339 c$ & $0.18037 b$ & $0.083 a$ & $0.0024 \mathrm{a}$ \\
\hline SED & & $0.0464 * * *$ & $0.0593 * * *$ & $0.0290 * * *$ & $0.0392 * * *$ & $0.02033 * * *$ & $0.0563^{n s}$ & $0.00322^{n s}$ \\
\hline $\mathrm{N}$ rate $(\mathrm{N})$ & 3 & & & & & & & \\
\hline No & & $0.1558 \mathrm{a}$ & $0.0958 \mathrm{a}$ & $0.097 \mathrm{a}$ & $0.054 \mathrm{a}$ & $0.0529 a$ & $0.022 \mathrm{a}$ & $0.0036 \mathrm{a}$ \\
\hline N70 & & $0.4048 \mathrm{c}$ & $0.2926 b$ & $0.105 \mathrm{a}$ & $0.123 \mathrm{a}$ & $0.0675 \mathrm{a}$ & $0.058 \mathrm{a}$ & $0.0072 \mathrm{a}$ \\
\hline N140 & & $0.3461 b c$ & $0.2937 b$ & $0.102 \mathrm{a}$ & $0.179 \mathrm{a}$ & $0.0972 \mathrm{a}$ & $0.111 \mathrm{a}$ & $0.0009 a$ \\
\hline $\mathrm{N} 210$ & & $0.2774 b$ & $0.3641 b$ & $0.115 \mathrm{a}$ & $0.133 a$ & $0.0586 \mathrm{a}$ & $0.148 \mathrm{a}$ & $0.0013 \mathrm{a}$ \\
\hline$S E D$ & & $0.0536 * * *$ & $0.0685 * * *$ & $0.0335^{n s}$ & $0.0452^{n s}$ & $0.02347^{n s}$ & $0.0650^{n s}$ & $0.00372^{n s}$ \\
\hline $\mathrm{Y} \times \mathrm{T}$ & 2 & $0.0656 * * *$ & $0.0839 * * *$ & $0.0410^{n s}$ & $0.0554^{n s}$ & $0.02875 * * *$ & $0.0796^{n s}$ & $0.00456^{n s}$ \\
\hline $\mathrm{Y} \times \mathrm{N}$ & 3 & $0.0758^{n s}$ & $0.0969 * *$ & $0.0473^{n s}$ & $0.0640^{n s}$ & $0.03319 *$ & $0.0919^{n s}$ & $0.00526^{n s}$ \\
\hline $\mathrm{T} \times \mathrm{N}$ & 6 & $0.0928 * * *$ & $0.1187 * *$ & $0.0580^{n s}$ & $0.0783^{n s}$ & $0.04066^{n s}$ & $0.1126^{n s}$ & $0.00644^{n s}$ \\
\hline $\mathrm{Y} \times \mathrm{T} \times \mathrm{N}$ & 6 & $0.1313^{n s}$ & $0.1678^{n s}$ & $0.0820^{n s}$ & $0.1108^{n s}$ & $0.05750 * * *$ & $0.1592^{n s}$ & $0.00911^{n s}$ \\
\hline
\end{tabular}

Values are mean; df, degree of freedom; and SED (in italics), Standard errors of difference for treatments and treatments interactions.

Values followed by same letter, do not differ significantly at $P<0.05 ; *=P<0.05, * *=$ $P<0.01 ; * * *=P<0.001 ;$ and $\mathrm{ns}=$ not significant. 
Figure 1. Mean air temperature and rainfall during 2013 and 2014 cropping seasons. Royal Agricultural University meteorological station $170 \times 62 \mathrm{~mm}(300 \times 300 \mathrm{DPI})$ 

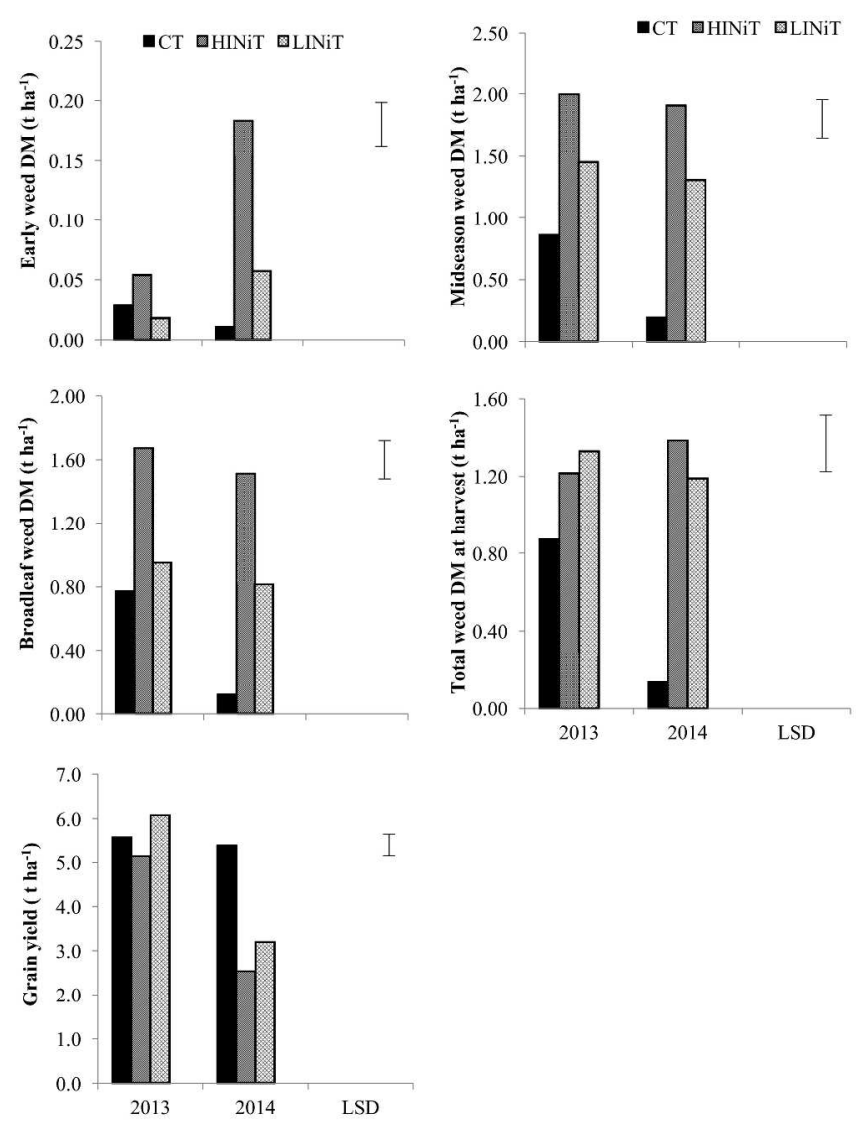

LSD, Fislıer's Least Significuant Difference al P! 0.05 for treatnents interaction means"

Aboveground weed biomass and spring wheat grain yield affected by year $\mathrm{x}$ tillage interaction $276 \times 386 \mathrm{~mm}(300 \times 300 \mathrm{DPI})$ 

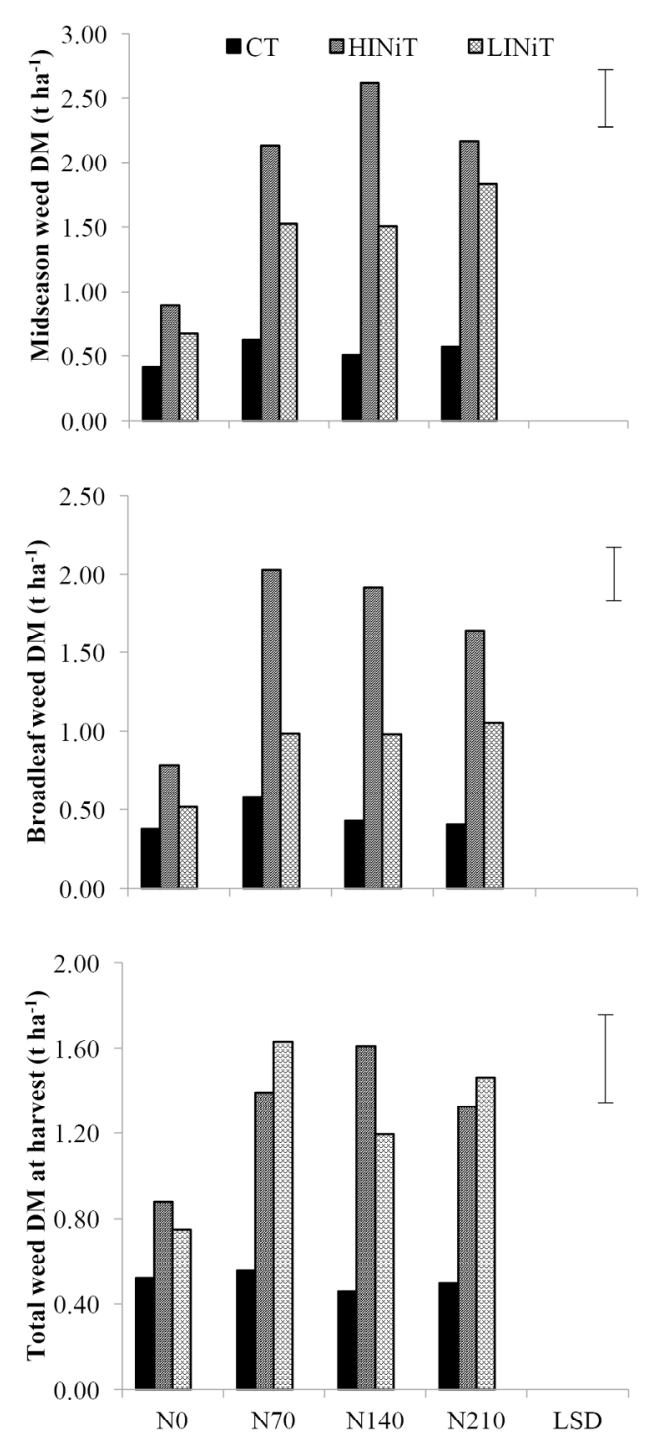

LSD, Fisher's Least Significant Difference at $P<0.05$ for treatments interaction means

Aboveground weed biomass and spring wheat grain yield affected by tillage $\mathrm{x} N$ management interaction $144 \times 210 \mathrm{~mm}(300 \times 300 \mathrm{DPI})$ 
1

2

3

4

5

6

7

8

9

10

11

12

13

14

15

16

17

18

19

20

21

22

23

24

25

26

27

28

29

30

31

32

33

34

35

36

37

38

39

40

41

42

43

44

45

46

47

48

49

50

51

52

53

54

55

56

57

58

59

60
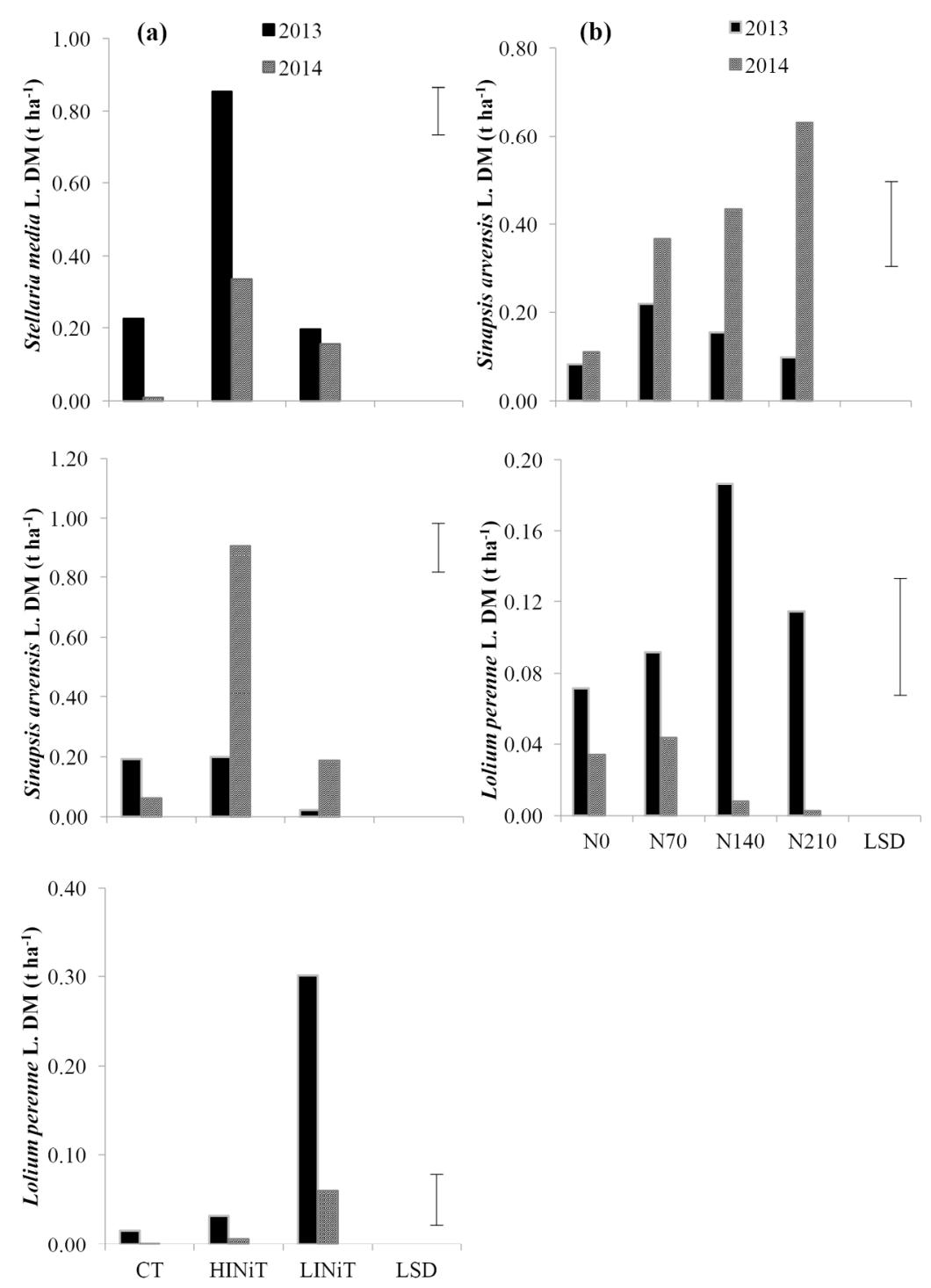

LSD, Fisher's Least Significant Difference at $P<0.05$ for treatments interaction means

Stellaria media, Sinapsis arvensis and Lolium perenne affected by year $\mathrm{x}$ tillage (a) and year $\mathrm{x} N$ management (b) interactions $156 \times 220 \mathrm{~mm}(300 \times 300$ DPI $)$ 

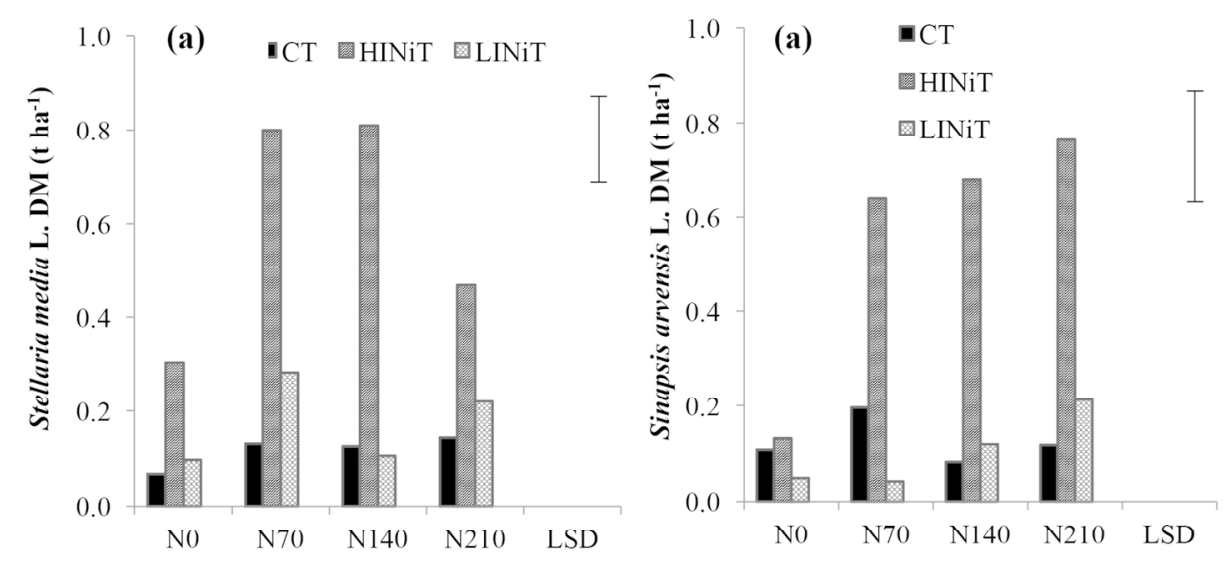

(b)

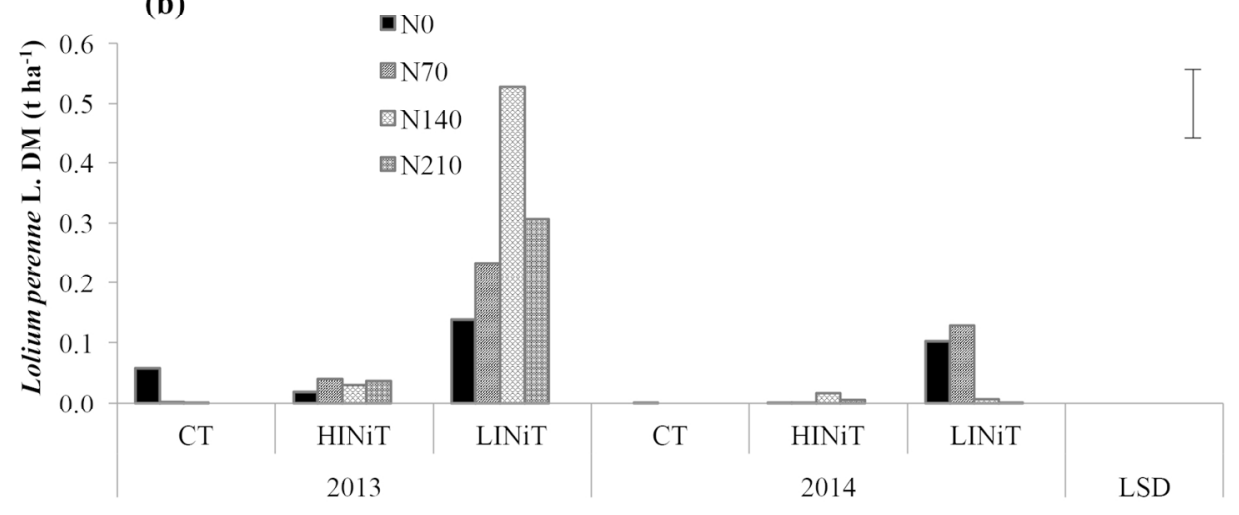

LSD, Fisher's Least Significant Difference at $P<0.05$ for treatments interaction means

Stellaria media and Sinapsis arvensis affected by tillage $\times \mathrm{N}$ management (a); and Lolium perenne affected by year $x$ tillage $\times \mathrm{N}$ management interaction $(\mathrm{b})$ $170 \times 170 \mathrm{~mm}(300 \times 300 \mathrm{DPI})$ 


\section{Annals of applied biology}

Society ms number:150364

Corresponding author: Dr Karen Rial-Lovera

address: Royal Agricultural University, School of Agriculture, Food and Environment, Stroud road Cirencester Gloucestershire GL7 6JS, UK.

tel:447775489306

fax:441285652531

email:karen.rial.lovera@gmail.com

Received date:2-Dec-15

Accepted date:26-Feb-16

Sent to publisher date:1 4-Mar-16

Article type: Research article (OA)

Additional material

$\square$ NO COLOUR

No. of line figures as EPS files:0 colour? No

No. of combination figures as EPS files:1 colour? No

No. of halftones as TIFF files:4 colour? No

No. of tables:5

No. of appendices:0

Supplementary material? No

Supporting documents

Exclusive licence to publish form (ELF)? No

Colour work agreement form (CWAF)? No

Permissions grant? No

Special instructions

aab_2015_0364. No colour Figures. 
1

2

3

4

5

6

7

8

10

11

12

13

15

16

17

18

19

20

21

22

23

24

25

26

27

28

29

30

34

35

36

37

38

39

40

41

42

43

44

45

46

47

48

49

50

51

52

53

54

55

56

57

58

59

60 